\title{
Practice-oriented Approach to Development of Leadership Competencies of Honors Students: the Project «The Territory of Intellectual and Liberal Inventions»
}

\author{
Tatyana V. Sedykh*, Vera V. Korshunova*, \\ Evgeniya V. Velichko, Alina A. Sosnovskaia, \\ Polina N. Grigorovech and Anastasia A. Bugaeva \\ Siberian Federal University \\ Krasnoyarsk, Russian Federation
}

Received 22.07.2021, received in revised form 8.08.2021, accepted 10.08.2021

\begin{abstract}
This article presents the results of the study dedicated to the development of leadership competencies of the students with high academic achievements based on the practice-oriented approach. The authors of the paper reveal the features of the development of leadership competencies of Honors College students based on a practice-oriented approach, present the theoretical justification and description of the project «The Territory of Intellectual and Liberal Inventions», develop the specific character of gamification of the process of development leadership competencies among students of the Honors College. The main methods of this study were a review of theoretical works devoted to leadership and leadership competencies, circumstances of the educational environment of the Honors College, and theory and practice of gamification; a survey of Siberian Federal University Honors students; substantiation, description and creating of the project «The Territory of Intellectual and Liberal Inventions»; a design of a gamification model of student leadership competencies' development process; a pilot experiment of this model, an analysis of the experiment results. The results of the conducted research reveal that the development of leadership competencies among gifted students based on a practice-oriented approach is actually and widely discussed by the educational community. The use of gamification allows intensifying the passing of the studied process. The materials of this article may be essential and beneficial for the researchers of development of leadership competencies, as well as for comparative studies in the field of teaching gifted students.
\end{abstract}

Keywords: leadership, leadership competencies, practice-oriented approach, gamification, gamification in education, gamification model of process, higher education, Honors education, Honors College.

Research area: pedagogy.

(C) Siberian Federal University. All rights reserved

* Corresponding author E-mail address: tvsedykh@yandex.ru, wera7@mail.ru 
Citation: Sedykh, T.V., Korshunova, V.V., Velichko, E.V., Sosnovskaia, A.A., Grigorovech, P.N., Bugaeva, A.A. (2021). Practice-oriented approach to development of leadership competencies of honors students: the project «The Territory of Intellectual and Liberal Inventions». J. Sib. Fed. Univ. Humanit. soc. sci., 14(9), 1331-1341. DOI: 10.17516/1997-1370-0823

\title{
Практико-ориентированный подход к развитию лидерских компетенций у студентов с высокими академическими достижениями: проект «Территория интеллектуальных и гуманитарных разработок»
}

\author{
Т.В. Седых, В.В. Коршунова, Е.В. Величко, \\ А.А. Сосновская, П.Н. Григорович, А.А. Бугаева \\ Сибирский федеральный университет \\ Российская Федерачия, Красноярск
}

\begin{abstract}
Аннотация. В статье представлены результаты исследования, посвященного развитию лидерских компетенций у студентов с высокими академическими достижениями на основе практико-ориентированного подхода. Авторы раскрывают здесь особенности развития лидерских компетенций студентов Honors College, представляют теоретическое обоснование и описание проекта «Территория Интеллектуальных и Гуманитарных Разработок», раскрывают специфику геймификации процесса развития лидерских компетенций у студентов НС. Основными методами изучения стали: обзор теоретических источников; опрос; обоснование проекта, разработка геймифицированной модели процесса развитие лидерских компетенций у студентов SibFU Honors College; пилотный эксперимент, анализ результатов эксперимента. Результаты свидетельствуют о том, что развитие лидерских компетенций у одаренных студентов актуально и широко обсуждается образовательным сообществом. Использование геймификации позволяет интенсифицировать протекание данного процесса. Материалы статьи могут быть полезны специалистам в сфере развития лидерских компетенций, а также использоваться для проведения сравнительных исследований обучения одаренных студентов.
\end{abstract}

Ключевые слова: лидерство, лидерские компетенции, практико-ориентированный подход, геймификация, геймификация в образовании, геймифицированная модель, высшее образование, Honors образование, Honors College.

Научная специальность: 13.00.00 - педагогические науки.

\section{Introduction}

An integral part of modern higher professional education is the development of leadership competencies, which are relevant due to a request from the professional community (employers) and from the future specialists (students). Lead- ership seems to stand out as a key word in the professional field.

The modern world needs a large number of specialists with developed leadership competencies who would generate and develop innovative ideas, create teams and communities 
that implement the ideas, organize and lead projects to translate these ideas into business, educational, cultural and social policy practice. The development of students' leadership competencies should be based on a practiceoriented approach, so that students can receive and use practical competencies already during training.

The education of honors students is focused on the development of leadership competencies. This is confirmed by a quote posted on the website of Purdue University Honors College, West Lafayette, «Leadership development is one of the pillars of an Honors College education.»>

Development of leadership competencies in honors education is realized in the format of a special educational program or its particular components and in the format of educational events.

Leadership educational program are realized in The University of Tennessee Honors College (Knoxville), Lesley University Honors College (Cambridge), Washington State University Honors College, Purdue University Honors College (West Lafayette), Valencia College (Seneff Honors College), etc.

There are two formats in educational programs. The first is a distributed educational program: the example of such a format is Firstand Second-Year Honors Leadership Programs of the Washington State University Honors College (WSU HC). These programs implement the development of leadership by making connections with engaging academic and industry leaders. It is also said that the students of the WSU HC are engaged in a variety of leadership opportunities throughout the university and beyond.

A concentrated educational program is the second example of an educational program, example of the concentrated format is a special program for new students in Honors College of Minnesota State University, Mankato. In the article 'Effects of Peer Mentorship on Student Leadership' Giovanna Walters, Kanak (2016) calls this program a summer orientation program in which first-year students and mentors (upper-class students) are involved. New students take an introductory course 'that fa- cilitates personal reflection and exploration in the three competency areas of leadership, research, and global citizenship'. According to M.E. Leichliter (2013), mentors serve as leaders by assisting with extracurricular activities, course teaching, tutoring, and other pursuits.

Honors College students participate in various educational events aimed at developing their leadership competencies. These educational events are organized by the National Collegiate Honors Council (NCHC), by Honors Colleges and outside organizations.

The events have different types: conferences, seminars, lectures, challenges etc. Here are some examples where members of the NCHC participated: The State Leadership Conference, The new Leadership TM Conference, The Leadership Seminar for Honors Leaders. The events organized by Honors Colleges: the CWU NEW Leadership TM Conference (hosted by the William O. Douglas Honors College and the Centre for Leadership and Community Engagement), Honors Congress Leadership Conference, The Honors College Activities Board (HCAB).

According to the website of the Valdosta State University, «Honors students are expected to engage in leadership activities and adhere to leadership principles». It is said that leadership involves collaborative experiences and is focused on implementing change, providing a solution, or making an improvement. This organization understands leadership as willingness to improve one's motivation, talents, vision, morale.

In our opinion, the most promising direction in the study of ways and means of development of leadership competencies in Honors Education is the organization of educational events.

\section{Theoretical framework}

\subsection{Leadership and leadership competencies}

To understand the features of the development of leadership competencies, it is necessary at the beginning to consider the essence of leadership, types of leadership competencies.

The definition of the term leadership has been discussed and debated for many decades but still there is no consensus. 
According to P. Northouse (2012), leadership is defined as «a process whereby an individual influences a group of individuals to achieve a common goal». The author pays attention to the components that could be identified as central to the leadership phenomenon: leadership is a process, leadership involves influence, leadership occurs in groups, and leadership involves common goals.

Theorists of management (E. Bogardus, K. Levin, M. Bradford, D. Goleman, L. Mumford, G. Limpman-Blumen) consider leadership in conjunction with the personality characteristics of a leader, strategies and styles of human behaviour in specific personal and professional situations, in the process of management of organizations and groups (teams).

In the educational context, the leadership indicator is the formation of leadership competencies. Leadership competencies were studied by the following authors: M. McCall, G. Hollenbeck, J. Brownwell, C. Sweeney, R. Müller, R. Turner, R. Ahmed. The majority of the researchers consider leadership competencies to be skills, abilities, proficiencies that a person generally acquires to practice being a leader, and to be an individual who is responsible for moving goals forward (Sweeney, 2017).

Leadership competencies can be divided into three main groups. Intellectual competencies suggest critical analysis and judgment, vision and imagination, strategic perspective. Managerial competencies suggest resource management, engaging communication, empowering, developing. And, finally, emotional competencies suggest self-awareness, emotional resilience, intuitiveness, interpersonal sensitivity, influence, motivation, conscientiousness (Muller, Turner, 2010).

A practice-oriented approach to development of leadership competencies of students implies the inclusion of project-based learning elements in educational programs, the involvement of students in project activities in the field of future professional activity and interdisciplinary research. The development of leadership competencies is most needed for students who have high academic achievements, that is, they have become successful in their own field, and who wish to become leaders.

\subsection{Honors Education}

Honors education as a part of higher education was created for students with high academic results who are aware of the value of education, have a clear understanding of their own educational goals, strive to build individual educational trajectories. Honors College is able to provide students with these instruments that are necessary to realize their potential.

L. Clark, J. Zubizarreta (2008) pay attention to the characteristics of honors (gifted, high-ability) students: they are motivated, have a self-concept, highly involved in extracurricular activities in college, involved in social sphere, prefer some independence in learning, experience perfectionism, feel relatively good about their academic abilities.

Peter C. Sederberg (2008) writes about Honors students' characteristics and gives the following statements, «ambitious students who commit themselves to the project of becoming educated members of a democratic society», «they are pursuing an education for life, citizenship, and career.»

The researcher examines the reasons for creating Honors Colleges, writes about colleges' values and educational directions, and characteristics of Contemporary Honors College. According to his survey the portrait of honors college is rather heterogeneous but colleges share the same principles and values. They collectively offer a wide variety of opportunities (courses, corporate culture), seem uniquely positioned to foster interdisciplinary degrees, every honors college has current standards for admission, mandatory requirement is a senior thesis or project.

Peter C. Sederberg (2008) claims that the main aim of Honors Colleges is «to build collaborative communities among colleagues, foster scholarly discussions, share resources, and repositories for faculty enrichment». It is important to organize the workshop and provide the campus with «cohorts of superb students» and to make all its resources opened to them.

The author considers leadership to be an integral characteristic of teachers and staff of Honors College, he is sure that teachers who behave like leaders are able to educate students with developed leadership competences. 
L. Clark (2008), J. Zubizarreta (2008) assert that Honors Education is connected with new «methods teaching strategies and theories about learning that form undercurrents in the larger conversations of best practice in higher education», also they claim that Honors program has «high-lighted and encouraged», as fundamental to their missions, innovative, creative approaches to teaching and learning.

Honors Education is an experimental educational platform, that is opened to new methods of teaching and learning. At the same time, each $\mathrm{HC}$ itself chooses the educational activities that are realized in it.

Siberian Federal University Honors College (SibFU Honors College) is based on the gaming technology. The majority of the educational path ways different types of games as the course tasks, also this Honors College provides game launch, game release.

\section{Statement of the problem}

The key problem of our research is the search for means of development leadership competencies among students of Honors College based on a practice-oriented approach in an open educational environment. To solve it, the following general objectives were defined:

1) To know the features of the process of development of Honors College students' leadership competencies (based on the example of SibFU Honors College);

2) To justify, describe and create an initiative project aimed at the development of student leadership competencies;

3) To design a gamification model of a development process of students' leadership competencies;

4) To apply the developed model in the activities of SibFU Honors College.

\section{Methods}

During the research, the following methods were used: a review of theoretical sources in the field of leadership and leadership competencies, features of Honors Colleges educational environment, a theory and practice of gamification; a survey of Siberian Federal University Honors students; substantiation, description and creating of the project «The Territory of
Intellectual and Liberal Inventions»; a design of a gamification model of the students' leadership competencies' development process; a pilot experiment of this model, an analysis of the experiment results.

\section{Discussion \\ 5.1. Features of the development \\ of Honors Students' leadership competencies}

The development of students' leadership competencies is one of the most significant goals of Honors Colleges. Considering the features of this process, four key aspects are identified.

The content aspect is associated with the choice of leadership competencies that should be developed among Honors students, and with the selection of educational content to be used.

The choice of leadership competencies should be based not only on theoretical assumptions, the requirements of educational and professional standards, but also on the opinions of the students themselves. It becomes expedient to preliminary study of the students' opinions on the most demanded leadership competencies in the modern world, diagnosing the level of formation of their respective competencies.

Traditionally, when developing leadership competencies, biographical materials of wellknown leaders, real professional cases, training exercises and games are used. However, most of them are based on the peculiarities of the development of society and the state in a specific historical era, which does not always correspond to the current trends in the development of science and practice. Therefore, the educational content used should describe up-to-date situations and reflect current technical, social, educational, political issues.

The procedural aspect implies the gradual passage of three phases by students: informing the basic principles and skills that support a particular leadership competence; appropriation of principles and skills to learners, as well as the formation of a positive attitude towards the chosen competence; presentation of target behaviour in the field of relevant competence. 
The instrumental aspect reveals a set of used active and interactive educational methods and technologies. At the same time, one of the most promising areas is gamification, suggesting the possibility of including gaming mechanisms and instruments in educational practice.

The environmental aspect determines the specificity of the behaviour of teachers and students in the process of development leadership competencies, as well as their interaction. Development of leadership competencies should occur not only at the initiative of the teaching staff, but also at the initiative of the students themselves, when they are included in the process of development appropriate educational programs and events.

A special attention should be paid to creating within the Honors College a community of people who are interested in developing their own leadership competencies. In the course of its development, such a community may take the form of a separate project, council, union, etc.

\subsection{Project "The Territory of Intellectual and Liberal Inventions» in SibFU Honors College}

In SibFU Honors College as well as in other Honors Colleges, a great attention is paid to the development of student leadership competencies based on a practice-oriented approach. The student initiative project «The Territory of Intellectual and Liberal Inventions» is aimed at developing leadership competences among students of Siberian Federal University.

The abbreviated name in Russian sounds as «TIGER» (TIGR - in original, Russian), and indicates the image of the tiger as a true leader. There is an African proverb that inspires, "An army of sheep led by a lion can defeat an army of lions led by a sheep». Don Christian even gives the term «Tiger leadership» and writes about tiger concentration and a leading position.

This project is actual to the Honors Community. The President of European Honors Council Marca V.C. Wolfensberger (2012) gives three main pillars of the Honors signature: academic competence, creating commu- nity, a balance between structure and freedom. The author even invokes her colleges for collaboration and networking because the researcher believes that the Honors community can provide a great experience both for Honors teachers and Honors students.

Thanks to the project «TIGER», the Honors community is improved. SibFU is aimed at supporting students' projects and supports our initiative student project, which also solves the problem of collaboration, consolidation and strengthening of the community.

The goal of the project is to organize the initiative student educational space «TIGER» on the basis of SibFU Honors College, aimed at developing leadership competencies and forming a personal agency of SibFU Honors College students through the use of a game approach.

The main objectives of the project:

1. To analyse the theoretical prerequisites for the development of leadership competencies and the formation of a personal agency of students with high academic results;

2. To develop a gamification model of a process of development of leadership competencies and the formation of a personal agency of SibFU Honors College students;

3. To organize and conduct gaming sessions with students of SibFU Honors College;

4. To reflect the results of gaming sessions;

5. To present the key results of the «TIGER» project to the educational and scientific community;

6. To study the basics of designing gamification systems.

To confirm the relevance of the request from students of SibFU Honors College, a survey of 30 students from the first admission was done.

Among the sought-after leadership competencies, the most frequent respondents noted: stress resistance (16 respondents, 53,30\%); listen to and heed (15 respondents, 50,00\%); the ability to organize others (15 respondents, $50,00 \%$ ); a willingness to be responsible for the team and the result even in case of failure (15 respondents, 50,00\%); learning ability, learning and the desire to develop (14 respondents, $46,70 \%$ ). 


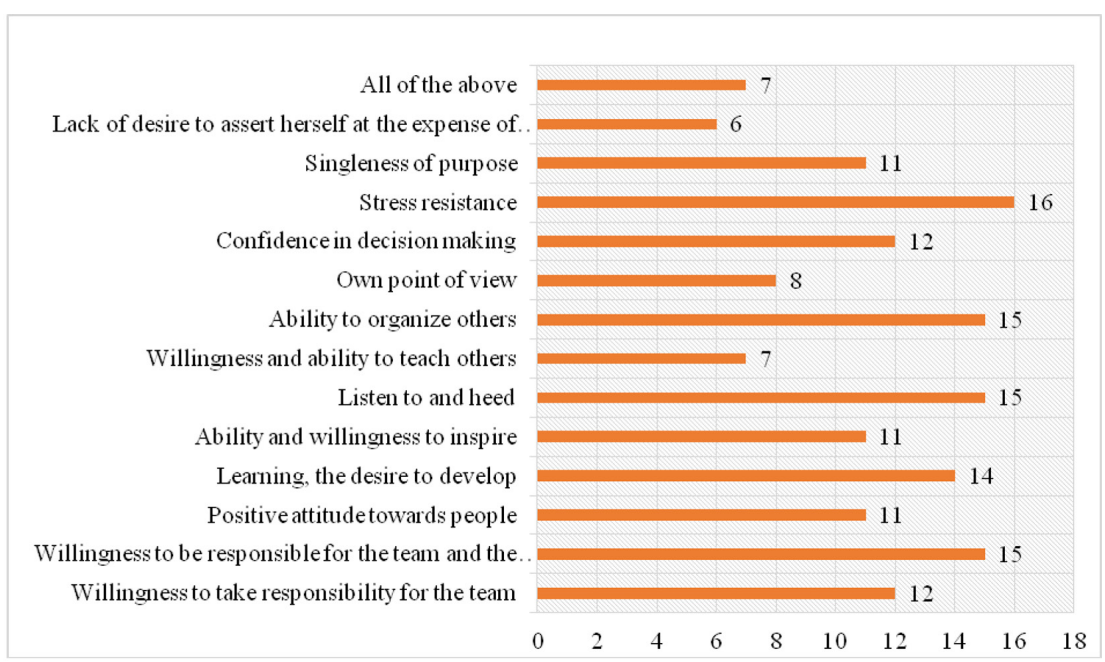

Fig. 1 The most sought-after leadership competencies

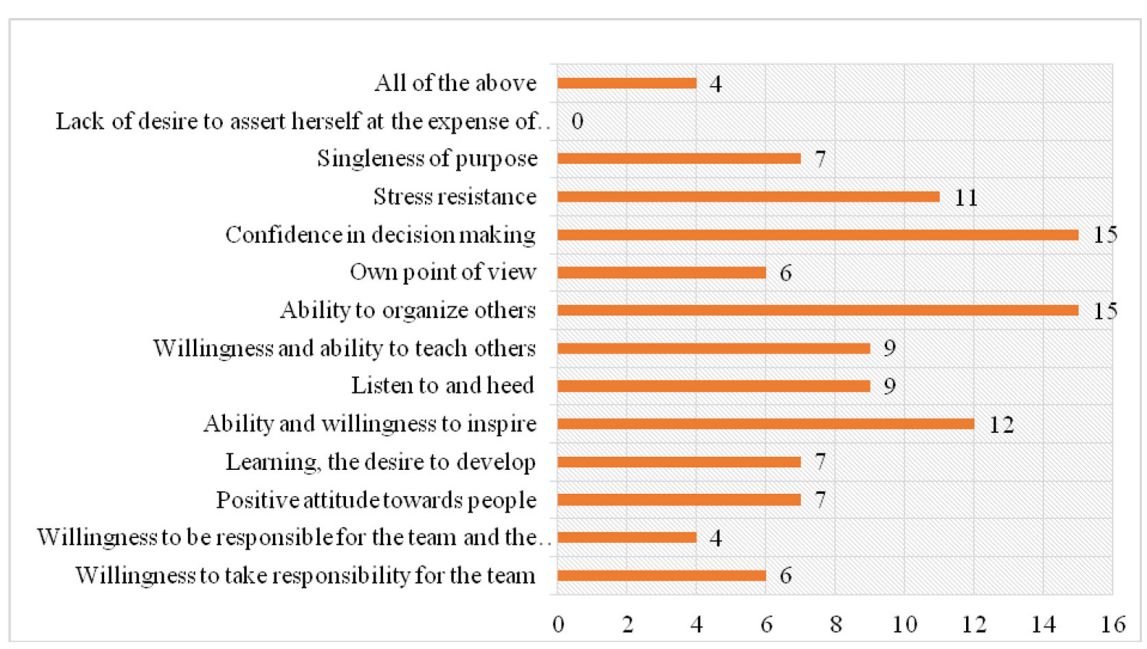

Fig. 2. Leadership competencies that students would like to develop

At the same time, respondents, answering the question: «Which of the above leadership competencies would you like to develop?» gave preference to not all previously chosen «soughtafter leadership competencies». The most relevant are the competencies are confidence in decision making (15 respondents, 50,00\%) and the ability to organize others (15 respondents, $50,00 \%)$.

Confidence in decision making and the ability to organize others were identified as priority for development among students in SibFU Honors College.

\subsection{A gamification model of a development process of Honors student leadership competencies}

The presence of a request from Honors students necessitated the search and selection of the most effective ways of developing leadership competencies in terms of open educational environment that would meet the principles of humanity, interactivity, and intensification of students' efforts in modern education.

The use of gamification allows making the process of education more interesting for stu- 
dents, focused on their mastery of values, command norms, actions in accelerated time. This is especially relevant in the context of an initiative educational environment that presupposes the specific influence of students on the course of the educational process.

During the development of the «TIGER» project, the basis of the ideas of K. Verbach, D. Hunter， I. Nefediev， M. Bronnikova， and others were used to design a gamification model of a development process of Honors student leadership competencies.

Gamification is considered by $\mathrm{K}$. Werbach, B. Hunter (2012) as using elements of a game and game mechanics in a non-game context, what allows achieving off-game goals through the use of a systematic approach to the choice of a storyline, game mechanics, and main attributes of the game.

However, according to I. Nefediev, M. Bronnikova (2021), gamification may be the introduction of additional game rules in any activity for engaging, retaining, and educating users in non-game contexts. In this case, three requisitions must be respected:

1. The game should be interesting and enthral players;

2. There should be direct, inextricable connection with reality;

3. Voluntary participation of players (when a player can independently decide to follow the rules of the game or not)

Designing of a gamification model of Honors student leadership competencies' development process is based on $\mathrm{K}$. Verbach's gamification design system 6-D (2021), which involved the completion of 6 basic stages «six steps D».

1. Define - define the goals of your business.

The main goal is to develop the most relevant leadership competencies of SibFU Honors College students in the context of initiative educational space through their participation in the preparation, conduction, and reflection on an interactive gaming sessions.

2. Delineate - describe the desired behaviour.

The basic characteristics of the target behaviour of the players:
1. Awareness of leadership as one of the key values of modern man, which is demonstrated during the discussion of educational content, an analysis of the results of gaming sessions.

2. Formed student's value attitude to leadership, manifesting in the pronounced positive emotional tinges of the terms «leader», «leadership», and «leadership competencies»;

3. Demonstration of the formation of relevant leadership competencies and their elements in the course of participation in the gaming session of the «TIGER» project, the SibFU Honors College educational process, professional and social activities, personal life.

3. Describe - describe the players.

The target audience is SibFU Honors College students who have high academic achievements. The approximate age range of players is from 17 to 23 years old.

These students combine extracurricular lessons at SibFU Honors College with their basic higher education programs, additional professional qualifications, research and social activities.

The most pressing needs for these players are self-realization (making a contribution to the common cause, including developing their own projects), communication (productive interaction with other people or groups of people), creativity (creating / generating and implementing innovative ideas and solutions).

They are initiative, focused on continuous personal and professional self-improvement, they create and realize individual educational trajectories.

4. Devise - develop activity loops.

There are four stages of integration players in game process:

Stage 1. Involvement: acquaintance with rules, teambuilding. Participants try to understand what the rules are and how to act in this educational environment.

Stage 2. Mastering: the rules and the game world is clear, the players understand how to act within a certain role, they begin to consciously use the role commandment when solving game problems.

Stage 3. Assimilation: participants acquired in the role so much that they begin to 
enrich it, at the level of improvisation they create their own line of conduction.

Stage 4. Self-Realization: players perceive the system as life, they do not realize that they are playing, everything is natural. Participants try to improve.

5.Don't forget - do not forget about entertainment.

The involvement of players and their motivation during participation in gamification occurs due to the choice of a specific game plot that is not directly related to the problems under consideration, but reflects the key indicators of the problem. In the conditions of the gamification model (created by us) of a development process of Honors student leadership competencies, the basic plot was a journey, which is a metaphor of the development path of all mankind and of an individual.

In addition, motivating players to continue developing their own leadership competencies can be activated by playing techniques that allow you to track your own progress of this process, cause excitement and inspiration. The example is the situation of accepting player's challenges for overcoming difficulties.

Creating an open, trusting sociopsychological atmosphere helps to increase the interest of participants in achieving their goals.

6. Deploy - use suitable tools.

The description of the tools of gamification is possible through the definition of the used game dynamics, mechanics and components. In accordance with the objectives, dynamics as progress, relationships, emotions were selected.

The main mechanics used were cooperation and the state that determines victory.

During game sessions the following components were used: achievements, badges, levels, social interaction, teams.

In the next paragraph a pilot experiment of the project is described.

\subsection{A pilot experiment to implement a gamification model of a development process of Honors student leadership competencies}

The testing of a developed gamification model of Honors student leadership competen- cies' development process was held in SibFU Honors College in a gaming session format.

The main aim of the game session was the development of Honors students' confidence in decision making and an ability to organize. These competencies were considered as the most demanded according to the survey results.

The strategic session of the development of the project «TIGER» was chosen as educational content, during which participants tried to determine the main characteristics of the strategic project management (vision, mission and goals, target audience, activity plans, team, risks, etc.)

The game story of space travel was selected for this session. A legend was presented to the participants, suggesting that they travel on the spaceship «TIGER-1» and interact with many intergalactic races in order to exchange the achievements of society and technology.

During the game session, the players were to learn useful qualities and competencies of each other, to assign roles within the spaceship team (roles were allocated according to the classification of E. Yourdon), to find out and present the most optimal solution of the proposed tasks and situations, to analyse the results of the game session.

The analysis of the outcome of the game session indicates the possibility to develop Honors students' leadership skills with the help of gamification. That is confirmed by the change in the behaviour of the players recorded during the observation, which is connected with the occupation of the leader's subjective position, the desire to influence the decision made by the team, and the active participation in the improvement of teamwork.

\section{Conclusion and recommendations}

Honors education is focused on the development of leadership competencies based on a practice-oriented approach in open educational space through the realization of educational programs and the organization of educational events. However, basically, the initiator for such activities is the administration and teaching staff of Honors Colleges. 
Providing students with the opportunity to participate in the creation and realization of educational events aimed at developing leadership competencies helps to increase their interest in the results of these events.

In Siberian Federal University the project «The Territory of Intellectual and Liberal Inventions» was created. It is oriented on the development of initiative student educational space, promoting development of leadership competencies and the formation of personal agency of honors students through the use of a game approach. The main advantage of the project is the use of a gamification model of a development process of honors student leadership competencies.

Hence, we believe that the experience presented may be of interest to teachers and students of Honors Colleges all around the world. Indeed, this experience could be used to educate gifted students and young professionals in the conditions of the long life learning system.

\section{References}

Campus NEW Leadership Conference. Central Washington University (2021). Available at: https://www.cwu.edu/douglas-honors/campus-new-leadership-conference (accessed 14 May 2021).

Clark, L., Zubizarreta, J. (2008). Inspiring Exemplary Teaching and Learning: Perspectives on Teaching Academically Talented College Students. University of Nebraska-Lincoln, NCHC Monographs Series, 218p.

Honors College Activities Board. Honors College Michigan State University (2021). Available at: https://honorscollege.msu.edu/programs/honors-college-activities-board.html (accessed 14 May 2021).

Honors Congress Leadership Conference. University of Central Florida (2021). Available at: https://events.ucf.edu/event/4105/honors-congress-leadership-conference/ (accessed 14 May 2021).

Honors College and Leadership. Washington State University Honors College (2021). Available at: https://honors.wsu.edu/leadership/ (accessed 14 May 2021).

Honors Leadership Activity. VSYOU Valdosta State University (2021). Available at: https://www.valdosta.edu/colleges/honors/forms/leadership-.php (accessed 14 May 2021).

Korshunova V. V. (2019). Practice-Oriented Approach To Training Tutors At The Siberian Federal University, In Journal of Siberian Federal. University. Humanities and Social Sciences, 12(2), $164-174$.

Leichliter, M.E. (2013). Creating opportunities for peer leadership in honors education, In Honors in Practice, 9, 155-161.

Marca, V. (2012). Teaching for Excellence: Honors Pedagogies revealed, In Waxmann Verlag GmbH (210)

Muller R., Turner R., (2010). Leadership competency profiles of successful project managers, In International Journal of Project Management, 28(5):437-448. DOI: 10.1016/j.ijproman.2009.09.00

Nefediev I., Bronnikova M. (2021). Gamification. Available at: https://stepik.org/course/50391 (accessed 14 May 2021)

Northouse, P. (2012). Leadership: Theory and Practice, In SAGE Publications, Inc; 6th edition (504)

Sedykh, T.V. (2020). Peculiarities of organization of educational process in the direction of «Learning navigation», In SibFU Honors College. Problems of modern pedagogical education, 66(2), 283-286.

Sederberg, P. (2008). The Honors College Phenomenon. University of Nebraska, Lincoln, NCHC Monographs Series. 174p.

Student Leadership. Purdue University Honors College (2021). Available at: https://honors.purdue.edu/ current-students/student-le.. (accessed 14 May 2021).

Sweeney, C. (2017). Paradigms, Principles, and Perception: Building Leadership Competencies from the Inside-out. Athens: ATINER'S Conference Paper Series, No: EDU2017-2282.

Smolyaninova O. G., Korshunova V. V. (2016) SibFU multicultural educational platform in the context of lifelong education, In Science and school, 4, 38-46.

Tiger Leadership. Concordia University Texas. (2021). Available at: http://christian.faculty.concordia. edu/2008/10/tiger-leadership.html (accessed 14 May 2021). 
Walters, G., Kanak, A. (2016). Effects of Peer Mentorship on Student Leadership, In Honors in Practice, $59-76$.

Walters, G., Kanak, A. (2016). Effects of Peer Mentorship on Student Leadership, In Honors in Practice, 59-76.

Werbach, K. (2021). Gamification. Available at: https://www.coursera.org/learn/gamification (accessed 14 May 2021).

Werbach, K., Hunter, D. (2012). For The Win: How Game Thinking Can Revolutionize Your Business, In Wharton Digital Press (148).

Yourdon, E. (1999). Death March: The Complete Software Developer's Guide to Surviving 'Mission Impossible' Projects, In Pearson PTR (240).

Zichermann, G., Linder, J. (2013). The Gamification Revolution: How Leaders Leverage Game Mechanics to Crush the Competition, In McGraw-Hill Education (256).

Zubizarreta, J. (2018). Honors Education as a global trend, In Honors College Conference. Krasnoyarsk 2018: International Conference Proceedings. Krasnoyarsk, November 30 - December 01, 2018, edit. By M. V. Tarasova. Krasnoyarsk, SibFU, 20-23. 